Proceedings

\title{
Ecotoxicity of EAN and Doped EAN Ionic Liquids ${ }^{\dagger}$
}

\author{
Juan José Parajó *, María Villanueva, Luis Miguel Varela and Josefa Salgado \\ NaFoMat Group, Applied Physic and Particle Physics Departments, University of Santiago de Compostela, \\ Campus Vida, 15782 Santiago, Spain; maria.villanueva@usc.es (M.V.); luismiguel.varela@usc.es (L.M.V.); \\ j.salgado.carbalo@usc.es (J.S.) \\ * Correspondence: juanjose.parajo@usc.es \\ + Presented at the 22nd International Electronic Conference on Synthetic Organic Chemistry, 15 \\ November-15 December 2018; Available Online: https://sciforum.net/conference/ecsoc-22. \\ Published: 14 November 2018
}

\begin{abstract}
The ecotoxicity of a nitrate-based ionic liquid (IL) and saturated mixtures with four nitrate salts towards the bioluminescent bacteria Vibrio fischeri, were tested in this work, using the Microtox $^{\circledR}$ standard toxicity test. The selected IL was Ethylammonium Nitrate (EAN) and the nitrate salts were Lithium Nitrate $\left(\mathrm{LiNO}_{3}\right)$, Calcium Nitrate $\left(\mathrm{Ca}\left(\mathrm{NO}_{3}\right)_{2}\right)$, Magnesium Nitrate $\left(\mathrm{Mg}\left(\mathrm{NO}_{3}\right)_{2}\right)$, and Aluminum Nitrate $\left(\mathrm{Al}\left(\mathrm{NO}_{3}\right)_{3}\right)$. The effective concentration $\left(\mathrm{EC}_{50}\right)$ of these mixtures was determined over three standard periods of time, namely 5, 15, and $30 \mathrm{~min}$. Results of EC 50 for pure EAN at $15 \mathrm{~min}$ are in relatively good concordance with the literature. To the best of our knowledge, no ecotoxicity studies have been performed for doped EAN. Similar results have been found for pure EAN and for EAN doped with $\mathrm{LiNO}_{3}$ and $\mathrm{Mg}\left(\mathrm{NO}_{3}\right)_{2}$, whose values indicated low toxicity. Nevertheless, the addition of $\mathrm{Ca}\left(\mathrm{NO}_{3}\right)_{2}$ and $\mathrm{Al}\left(\mathrm{NO}_{3}\right)_{3}$ cause an increase in the ecotoxicity of EAN, especially for the IL doped with $\mathrm{Al}\left(\mathrm{NO}_{3}\right)_{3}$, which present values associated to highly toxic compounds, comparable even with benzene or atrazine.
\end{abstract}

Keywords: ecotoxicity; ionic liquids; Vibrio fischeri; microtox; doped

\section{Introduction}

Ionic Liquids (ILs) are generically regarded as environmentally "harmless" and thus, accepted as "non-toxic" [1]. However, owing to the limitless possibilities in their design, their ecotoxicity is still poorly known. Due to their ionic character, almost all ILs are soluble in water [2], which can represent an environmental problem. Different studies showed that ILs present some toxicity [3,4], withtheir environmental impact strongly dependent on the cation and anion used to synthesized them [5,6]. Under of the REACH (Registration, Evaluation, Authorisation and Restriction of Chemicals) regulation [7], an accurate knowledge on the toxicity of a substance is required before their application and/or commercialization. Focusing on the use of ILs as: Electrolyte for chemical devices, base lubricants or lubricant additives, or even as potential working fluids for absorption heat pumps, a spill of IL can occur, and it is necessary to know their possible environmental effects. Although, thus far, toxicity of ILs have been evaluated through different models, it is extremely important to study the effects of their ecotoxicity across various trophic levels. In addition, the knowledge on the relation between the chemical structure and the toxic effect is essential for the future design of greener solvents. The ecotoxicity of pure and doped ethylammonium nitrate (EAN) with four different ionic salts has been analyzed using the standard organism Vibrio fischeri. 


\section{Materials and Methods}

\subsection{Chemicals}

The main characteristics of selected Ionic Liquid (IL), EAN, are indicated in Table 1. To obtain doped EAN, lithium, calcium, magnesium, and aluminum nitrate salts were used.

Table 1. Chemical structure, identification number, molecular mass, and purity of EAN and nitrate salts.

\begin{tabular}{|c|c|c|c|c|}
\hline $\begin{array}{c}\text { Name } \\
\text { Molecular Mass }\left(\mathrm{g} \cdot \mathrm{mol}^{-1}\right) \\
\end{array}$ & $\begin{array}{l}\text { Abbreviation } \\
\text { CAS Number }\end{array}$ & Chemical Structure & $\begin{array}{c}\text { Purity } \\
\text { Provenance }\end{array}$ & Water Content \\
\hline $\begin{array}{l}\text { Ethylammonium Nitrate } \\
108.0965\end{array}$ & $\begin{array}{c}\text { EAN } \\
22113-86-6\end{array}$ & + & $\begin{array}{l}>0.999 \\
\text { Iolitec }\end{array}$ & $<100$ ppm \\
\hline $\begin{array}{l}\text { Lithium Nitrate } \\
68.946\end{array}$ & $\begin{array}{c}\mathrm{LiNO}_{3} \\
7790-69-4\end{array}$ & $\mathrm{Li}^{+}$ & $\begin{array}{l}>0.999 \\
\text { Merck }\end{array}$ & $<100$ ppm \\
\hline $\begin{array}{c}\text { Calcium Nitrate } \\
\text { Tetrahydrate } \\
236.088\end{array}$ & $\begin{array}{c}\mathrm{Ca}\left(\mathrm{NO}_{3}\right)_{2} \cdot 4 \mathrm{H}_{2} \mathrm{O} \\
13477-34-4\end{array}$ & {$\left[{ }^{2}\right.$} & $\begin{array}{l}>0.999 \\
\text { Merck }\end{array}$ & $30 \mathrm{wt} \%$ \\
\hline $\begin{array}{c}\text { Magnesium Nitrate } \\
\text { Hexahydrate } \\
256.3\end{array}$ & $\begin{array}{c}\mathrm{Mg}\left(\mathrm{NO}_{3}\right)_{2} \cdot 6 \mathrm{H}_{2} \mathrm{O} \\
13446-18-9\end{array}$ & {$\left[{ }^{0}\right.$} & $\begin{array}{l}>0.999 \\
\text { Merck }\end{array}$ & $42 \mathrm{wt} \%$ \\
\hline $\begin{array}{l}\text { Aluminium Nitrate Nonahydrate } \\
374.996\end{array}$ & $\begin{array}{l}\mathrm{Al}\left(\mathrm{NO}_{3}\right)_{3} \cdot 9 \mathrm{H}_{2} \mathrm{O} \\
\quad 7784-27-2\end{array}$ & $\mathrm{Al}^{+3}$ & $\begin{array}{l}>0.999 \\
\text { Merck }\end{array}$ & $43{ }_{w t} \%$ \\
\hline
\end{tabular}

The different solutions of salts were prepared by mixing both components with the help of an ultrasound bath and a magnetic stirrer during 24 to $48 \mathrm{~h}$. Saturated solutions have been reached using the hydrated salts by increasing molality in intervals of $0.5 \mathrm{~mol} \cdot \mathrm{kg}^{-1} \mathrm{until}$ saturation point at room temperature.

\subsection{Experimental Section}

Microtox ${ }^{\circledR}$ Toxicity Test [8] was used to assess the toxicity of the tested chemical compounds through the inhibition of the luminescence of the marine bacteria Vibrio fischeri. Exposure to a toxic substance caused a disruption of the respiratory process of the bacteria, and the light production was directly proportional to the metabolic activity of the bacterial population. This test was performed using a range of diluted aqueous solutions (from 0 to $81.9 \%$ ) of each tested compound ( $100 \%$ corresponds to a known concentration of a stock solution). After 5, 15, and $30 \mathrm{~min}$ of exposure to the IL, the light output of the luminescent bacteria was measured and compared with the light output of a blank control sample (without the presence of the IL). These data were used to estimate the concentrations that promote $50 \%, 20 \%$, and $10 \%$ of luminescence inhibition (corresponding to the effective concentration, $\mathrm{EC}_{50}, \mathrm{EC}_{20}$, and $\mathrm{EC}_{10}$, respectively) and the corresponding $95 \%$ confidence intervals through a non-linear regression, using the least-squares method to fit the data to the logistic equation.

\section{Results and Discussion}

Figure 1 shows the typical behavior of Vibrio fischeri bacteria when it is exposed to a toxic, in this case $\%$ of luminescence relative to control versus concentration, of EAN $+\mathrm{Al} 2 \mathrm{~m}$. Furthermore, the 
effective concentration values $\left(\mathrm{EC}_{10}, \mathrm{EC}_{20}\right.$, and $\left.\mathrm{EC}_{50}\right)$ of the different compounds have been published in Table 2.

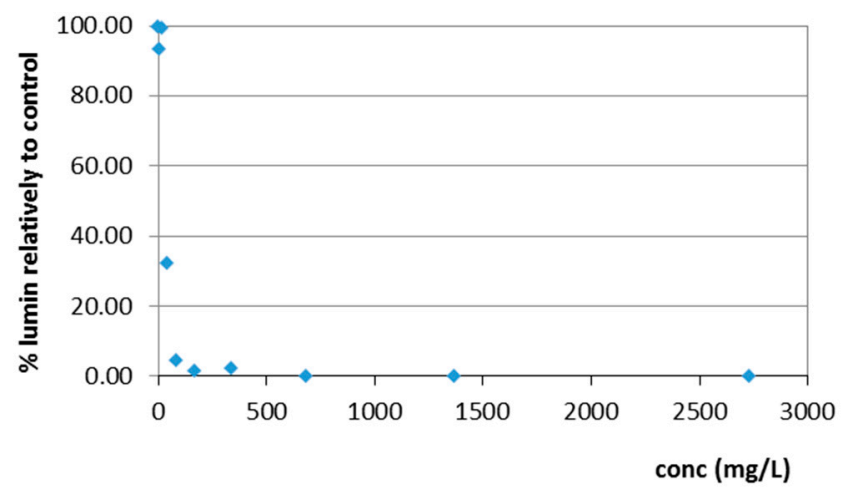

Figure 1. Effective concentration (EC)50 at 30 mins for ethylammonium nitrate $(\mathrm{EAN})+\mathrm{Al} 2 \mathrm{~m}$.

Table 2. Mean effective concentration values (EC $\left.10, \mathrm{EC}_{20}, \mathrm{EC}_{50}\right)$ in $\mathrm{mg} \mathrm{L}^{-1}$ and the respective $95 \%$ confidence intervals (CI), obtained after 5, 10, and $30 \mathrm{~min}$ of exposure of the marine bacteria Vibrio fischeri.

\begin{tabular}{|c|c|c|c|c|}
\hline IL & Time/min & $\begin{array}{l}\text { EC50 (Lower Limit; } \\
\text { Upper Limit)/mg·L-1 }\end{array}$ & $\begin{array}{l}\mathrm{EC}_{20} \text { (Lower Limit; } \\
\text { Upper Limit)/mg } \cdot \mathrm{L}^{-1}\end{array}$ & $\begin{array}{l}\text { EC10 (lower Limit; } \\
\text { Upper Limit)/mg } \cdot \mathrm{L}^{-1}\end{array}$ \\
\hline \multirow{3}{*}{ EAN } & 5 & $12,582(8186 ; 16977)$ & $4314(1548 ; 7081)$ & $2304(248 ; 4361)$ \\
\hline & 15 & $10,665(6650 ; 14680)$ & $3236(951 ; 5522)$ & $1609(56 ; 3163)$ \\
\hline & 30 & $9711(6561 ; 12860)$ & $3012(1264 ; 4761)$ & $1517(332 ; 2703)$ \\
\hline \multirow{3}{*}{$\mathrm{EAN}+\mathrm{Li} 2 \mathrm{~m}$} & 5 & $13,911(12469 ; 15232)$ & 8892 (7412; 10373) & $6842(5316 ; 8368)$ \\
\hline & 15 & $11,210(9613 ; 12808)$ & $7495(5603 ; 9386)$ & $5920(3841 ; 8000)$ \\
\hline & 30 & 9706 (7233; 12179) & $6145(3301 ; 8988)$ & $4701(1744 ; 7658)$ \\
\hline \multirow{3}{*}{$\mathrm{EAN}+\mathrm{Ca} 1 \mathrm{~m}$} & 5 & $7354(5672 ; 9036)$ & $3939(2427 ; 5450)$ & $2732(1304 ; 4159)$ \\
\hline & 15 & $6064(4343 ; 7784)$ & $2858(1475 ; 4240)$ & $1938(632 ; 3046)$ \\
\hline & 30 & $4502(3067 ; 5937)$ & $1804(800 ; 2808)$ & $1059(263 ; 1849)$ \\
\hline \multirow{3}{*}{$\mathrm{EAN}+\mathrm{Mg} 2 \mathrm{~m}$} & 5 & $12,724(10834 ; 14615)$ & $7471(5520 ; 9421)$ & $5469(3551 ; 7387)$ \\
\hline & 15 & $13,384(12522 ; 14247)$ & 8933 (7887; 9979) & $7049(5925 ; 8174)$ \\
\hline & 30 & $14,266(13128 ; 15403)$ & 10,222 (8450; 11994) & $8409(6357 ; 10461)$ \\
\hline \multirow{3}{*}{$\mathrm{EAN}+\mathrm{Al} 2 \mathrm{~m}$} & 5 & $45(32 ; 58)$ & $15(8 ; 22)$ & $8(3 ; 13)$ \\
\hline & 15 & $37(33 ; 41)$ & $23(18 ; 27)$ & $17(12 ; 21)$ \\
\hline & 30 & $32(29 ; 36)$ & $19(15 ; 23)$ & $14(10 ; 18)$ \\
\hline
\end{tabular}

Results found in Table 2 demonstrate the well-known effect of time in the toxicity results, which normally describes the lowest EC values for the highest time of exposure. Montalbán et al. [9] have found lower values than ours for pure EAN in the effective concentration for EC50 at 15 min of 2256 $\mathrm{mg} \cdot \mathrm{L}^{-1}$, this value is quite different than ours, although both of them can be considered as non-toxic according to GHS (Globally Harmonized System of Classification and Labeling of Chemicals) [10]. Similar results have been found for the solutions of lithium and magnesium (non-toxic), as well as for calcium solution, although in this case it was a bit more toxic. On the other hand, the aluminum solution can be categorized as Acute III, which is comparable with atrazine and benzene [11]. 


\section{Conclusions}

The main conclusion of this work is that ethylammonium nitrate and three of the studied salts solutions are non-toxic, although when the studied solution is saturated with aluminum, it is highly toxic.

Funding: This work was supported by the projects GRC ED431C 2016/001 (Xunta de Galicia, Spain) and MAT2017-89239-C2-1-P (Ministerio de Economía, Industria y Competitividad, Spain).

Acknowledgments: Authors thank J.M. Sánchez for their technical support.

Conflicts of Interest: The authors declare no conflict of interest.

\section{References}

1. Rogers, R.D.; Seddon, K.R. Green Industrial Applications of Ionic Liquids; Springer: Berlin, Germany, 2002; ISBN9789401001274.

2. Freire, M.G.; Santos, L.M.N.B.F.; Fernandes, A.M.; Coutinho, J.A.P.; Marrucho, I. An overview of the mutual solubilities of water-imidazolium-based ionic liquids systems. Fluid Phase Equilib. 2007, 261, 449-454, doi:10.1016/j.fluid.2007.07.033.

3. Pawłowska, B.; Biczak, R. Evaluation of the effect of tetraethylammonium bromide and chloride on the growth and development of terrestrial plants. Chemosphere 2016, 149, 24-33, doi:10.1016/j.chemosphere.2016.01.072.

4. Salgado, J.; Parajó, J.J.; Teijeira, T.; Cruz, O. Proupin, J.; Villanueva, M.; Rodríguez-Añon, J.A.; Verdes, P.V.; Reyes, O. New insight into the environmental impact of two imidazolium ionic liquids. Effects on seed germination and soil microbial activity. Chemosphere 2017, 185, 665-672, doi:10.1016/j.chemosphere.2017.07.065.

5. Petkovic, M.; Seddon, K.R.; Rebelo, L.P.N.; Pereira, C.S. Ionic liquids: A pathway to environmental acceptability. Chem. Soc. Rev. 2011, 40, 1383-1403, doi:10.1039/c004968a.

6. Santos, J.I.; Gonçalves, A.M.M.; Pereira, J.L.; Figueiredo, B.F.H.T.; eSilva, F.A.; Coutinho J.A.P.; Ventura, S.P.M.; Gonçalves, F. Environmental safety of cholinium-based ionic liquids: Assessing structure-ecotoxicity relationships. Green Chem. 2015, 17, 4657-4668, doi:10.1039/C5GC01129A.

7. REACH. Available online: https://ec.europa.eu/growth/sectors/chemicals/reach_en (accessed on 16 April 2019).

8. Microbics Corporation. Microtox ${ }^{\circledR}$ Manual -A Toxicity Testing Handbook; Microbics Corporation: Carlsbad, CA, USA, 1992; pp. 1-5.

9. Montalbán, M.G.; Hidalgo, J.M.; Collado-González, M.; Díaz-Baños, F.G.; Víllora, G. Assessing chemical toxicity of ionic liquids on Vibrio fischeri: Correlation with structure and composition. Chemosphere 2016, 155, 405-414, doi:10.1016/j.chemosphere.2016.04.042.

10. United Nations. Globally Harmonized System of Classification and Labeling of Chemicals (GHS), 4th ed.; United Nations: New York, NY, USA, 2011.

11. Ventura, S.P.M.; eSilva, F.A.; Gonçalves, A.M.M.; Pereira, J.L.; Gonçalves, F.; Coutinho, J.A.P. Ecotoxicity analysis of cholinium-based ionic liquids to Vibrio fischeri marine bacteria. Ecotox. Environ. Saf. 2014, 102, 48-54, doi:10.1016/j.ecoenv.2014.01.003.

(C) 2019 by the authors. Licensee MDPI, Basel, Switzerland. This article is an open access article distributed under the terms and conditions of the Creative Commons Attribution (CC BY) license (http://creativecommons.org/licenses/by/4.0/). 